\title{
Outra vez Bazárov
}

\section{Once again \\ Bazarov}

Autor: Aleksandr Herzen Tradutores: Priscila Nascimento Marques e Letícia Mei

Edição: RUS Vol. 12. № 18

Data: Abril de 2021 


\title{
Outra vez Bazárov ${ }^{1}$
}

\author{
Aleksandr Herzen \\ Tradução de \\ Priscila Nascimento Marques* \\ e Letícia Mei**
}

Resumo: 0 ensaio epistolar de Aleksandr Herzen foi composto em 1868 e constitui uma acirrada polêmica do autor com "os novos homens" da década de 1860, os "filhos", segundo a categoria fundada pelo romance de Turguêniev. No texto, Herzen, um eminente representante da geração dos "pais", acerta as contas com as representações estereotipadas da geração à qual pertence, apontando os erros, as injustiças e os desvios dos "filhos". Por fim, o autor entra na disputa pelo conceito filosófico de niilismo, reelaborando-o em outras bases.

\begin{abstract}
Aleksandr Herzen's epistolary essay was composed in 1868 and presents the author's acute polemic towards the "new men" of the 1860s, the "children", according to the category devised by Turgenev in his famous novel. In the text, Herzen, an eminent representative of the generation of the "fathers", settles the score with stereotypical views of the generation he belongs to, indicates the "children's" mistakes, injustices and deviations. Finally, the author steps into the dispute for the philosophical concept of nihilism, reworking it on a new basis.
\end{abstract}

Palavras-chave: Niilismo; Dezembristas; Filosofia russa; Literatura Russa Keywords: Nihilism; Dezembrists; Russian Philosophy; Russian Literature 


\section{Primeira carta}

*Professora adjunta da Faculdade de Letras da Universidade Federal do Rio de Janeiro (UFRJ). Mestra e doutora pelo Programa de Pós-Graduação em Literatura e Cultura Russa, da Faculdade de Filosofia Letras e Ciências Humanas, Universidade de São Paulo. Realiza estágio de pós-doutorado no mesmo programa. https:// orcid.org/0000-0002-7111-6372; priscilamarques@letras.ufrj.br

** Mestra e doutora pelo Programa de Pós-Graduação em Literatura e Cultura Russa, da Faculdade de Filosofia Letras e Ciências Humanas, Universidade de São Paulo. https://orcid.org/0000-0002-93151857; leticiamei@usp.br

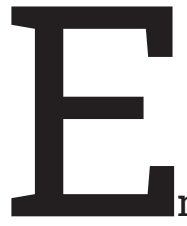

$\mathrm{m}$ vez de uma carta, querido amigo, envio-lhe uma dissertação, e ademais uma dissertação inacabada. Depois de nossa conversa, reli o artigo de Píssariev sobre Bazárov, que eu havia esquecido completamente, e alegrei-me por isso, ou melhor, não por ter esquecido, mas por ter relido.

É um artigo que confirma meu ponto de vista. Em sua unilateralidade, ele é mais correto e notável do que pensaram seus opositores.

Se Píssariev havia compreendido corretamente o Bazárov de Turguêniev, até então isso não me interessava. Importava ele ter reconhecido a si próprio e aos seus em Bazárov e acrescentado aquilo que faltava no livro. Quanto menos Píssariev se agarrou aos moldes em que os pais zangados tentavam enquadrar o filho teimoso, mais livremente ele transferiu-lhe seu ideal.

"Mas de que nos interessa o ideal do senhor Píssariev? Píssariev, um crítico corajoso, escreveu muito e sobre tudo, às vezes até sobre temas que conhecia, mas isso não confere ao seu ideal o direito de ter atenção pública."

A questão é justamente que não se trata de seu ideal pessoal, mas de um ideal que foi defendido pela geração jovem antes do Bazárov de Turguêniev e depois dele, e que se personificou não apenas em diferentes heróis de novelas e romances, mas em pessoas vivas, que tentavam tomar o bazarovismo como base para suas ações e palavras. O que Píssariev diz eu ouvi e vi dezenas de vezes; ele revelou ingenuamente o pensamento

1 Traduzido a partir de: Herzen, A. I. Sobránie Sotchiniénii v trídtsati tomákh [Obra reunida em trinta volumes]. Moscou: Izdatelstvo Akademii Nauk SSSR, 1960. Volume 20, livros 1 (texto principal) e 2 (comentários). As notas de rodapé não identificadas são de Z. V. Smirnov e I. G. Ptúchkin, editores da edição consultada. Dos mesmos autores é o comentário apresentado ao final. As tradutoras agradecem a inestimável colaboração de Raquel Toledo, tanto na tradução quanto na revisão deste material. 
íntimo de todo um círculo e, ao reunir raios dispersos em um foco, iluminou o Bazárov típico.

Para Turguêniev, Bazárov é mais do que alheio, para Píssariev, é mais do que seu; para tal exame será preciso, obviamente, tomar a perspectiva pela qual ele vê em Bazárov seu desideratum. ${ }^{2}$

Os opositores de Píssariev se assustaram com sua imprudência; ao renegar o Bazárov de Turguêniev como sendo uma caricatura, eles se afastaram ainda mais do seu duplo transformado; era-lhes desagradável que Píssariev batesse o pé, mas isso não quer dizer que ele o tenha compreendido incorretamente. $^{3}$

Píssariev conhece o coração de seu Bazárov por completo, ele se confessa com ele. Ele diz: "É possível que, no fundo de sua alma, Bazárov reconheça muito do que ele nega em palavras, e é possível que justamente o reconhecido, o que fora ocultado, salve-o da decadência e da aniquilação moral". Parece-nos muito importante essa indiscrição tão profundamente perscrutada na alma alheia.

Adiante, Píssariev caracteriza seu herói da seguinte forma: "Bazárov é extraordinariamente vaidoso, mas sua vaidade é imperceptível [claro que não se trata do Bazárov de Turguêniev] justamente por ser colossal. Só seria possível satisfazer Bazárov com toda a eternidade de uma atividade em constante expansão e de uma satisfação em constante crescimento". ${ }^{4}$

\footnotetext{
2 Do latim, aquilo que se deseja, almeja.

3 Herzen se refere aos artigos críticos de M. A. Antonóvitch publicados n'0 Contemporâneo sobre o romance de Turguêniev Pais e filhos. Já em seu primeiro artigo, "O Asmodeus de nosso tempo" (O Contemporâneo, n. 3, 1962), publicado ao mesmo tempo em que "Bazárov" (Palavra russa, n. 3, 1862), Antonóvitch, em contraposição a Píssariev, confirmou que Turguêniev, ao defender os "pais", caluniou os "filhos". No artigo "Romances contemporâneos" (0 Contemporâneo, n. 4, 1864), Antonóvitch afirma que "Pais e filhos e Mar agitado são irmãos de sangue" e que os "filhos críticos (trata-se de Píssariev, uma vez que é citado um trecho do artigo "Bazárov") aceitaram a caricatura de Turguêniev como sendo seu retrato", e assim "ridicularizaram-se diante dos pais", os quais têm razão em dizer-Ihes: "como devem ser bons estes que tomam Bazárov por seu ideal". A polêmica com A palavra russa sobre o significado da imagem de Turguêniev continuou em outros artigos de Antonóvitch publicados entre 1864 e 1865, bem como nas crônicas de Saltykov-Schedrin em "Nossa vida social".
}

4 Os jovens gostam de se expressar em incomensurabilidades diversas e impressionar a 
Em tudo e em toda parte, Bazárov age apenas como lhe apraz ou como lhe parece proveitoso e oportuno, ele é dirigido apenas pelo capricho ou pelo cálculo pessoal. Seja acima, fora ou dentro de si, ele não reconhece nenhuma instância reguladora. Diante de si não há quaisquer objetivos elevados, no intelecto não há qualquer intento elevado, e apesar de tudo suas forças são descomunais. Se o bazarovismo é uma doença, ele é o mal do nosso tempo e precisamos padecer dele, a despeito de quaisquer amputações e paliativos.

Bazárov olha para as pessoas de cima para baixo, raramente se dá o trabalho de ocultar sua atitude meio desdenhosa, meio paternalista, tanto em relação aos que o odeiam quanto aos que o ouvem. Ele não ama ninguém. Ele considera absolutamente supérfluo constranger-se com o que quer que seja. Seu cinismo tem duas expressões, uma externa e outra interna, o cinismo dos pensamentos e sentimentos e o cinismo das maneiras e das expressões. A atitude irônica em relação a todo tipo de sentimento, à mentalidade, ao lirismo, constitui a essência do cinismo interno. A expressão tosca dessa ironia e a rispidez imotivada e sem objetivo no tratamento com os outros estão relacionadas ao cinismo externo. Bazárov não é apenas um empírico, é antes de tudo um sujeito abrutalhado. Entre os admiradores de Bazárov encontram-se, possivelmente, pessoas que se encantam com suas maneiras toscas - traços de vida de seminarista - e que imitam essas maneiras, as quais são em todo caso um defeito e não um mérito. ${ }^{5}$

imaginação de formas infinitamente grandiosas. Essa última frase me lembra Karl Moore, Ferdinand e Don Carlos. (N. do A.) Ref. a três personagens jovens e rebeldes, respectivamente, das peças Os Bandoleiros (1781), Intriga e Amor (1783) e Don Carlos (1787/88), do escritor e filósofo alemão Friedrich Schiller. ( $\mathrm{N}$ das T.)

5 A profecia se realizou. Coisa estranha é a interdependência das pessoas em relação aos livros e dos livros em relação às pessoas. 0 livro toma toda a constituição da sociedade na qual ele surge, generaliza-a, torna-a mais evidente e aguda, e em seguida é superado por ela. Os originais fazem uma caricatura de seus retratos fortemente sombreados e rostos reais ganham vida em suas sombras literárias. No final do século passado, todos os homens alemães se confundiam com Werther, todas as mulheres alemãs eram como Charlotte; no começo deste século os Werther universitários se converteram em "bandoleiros", não verdadeiros, mas schillerianos. Os jovens russos surgidos depois de 1862 são quase todos oriundos de 0 que fazer?, com o acréscimo de alguns traços bazarovistas. (N. do A.) 
Tais pessoas amiúde se formam no ambiente cinzento da vida do trabalho, as mãos ficam ásperas pelo trabalho duro, as maneiras ficam ásperas, os sentimentos ficam ásperos, a pessoa se fortalece e expulsa o espírito sonhador da juventude, livra-se do sentimentalismo choroso; é impossível sonhar no trabalho, a pessoa olha para o sonho como para uma fantasia, típica da ociosidade e do mimo senhorial, ela considera os sofrimentos morais como sonhos, as aspirações e os feitos morais são invencionices e absurdos. Ela sente asco pelo frasismo.

Em seguida, Píssariev apresenta a árvore genealógica de Bazárov: Oniéguin e Petchórin deram à luz os Rúdin e os Beltov, estes geraram Bazárov. (Se os dezembristas foram omitidos voluntária ou involuntariamente, isso eu não sei.)

Pessoas cansadas e entediadas são substituídas por pessoas que se lançam para a ação, a vida rejeita ambas como imprestáveis e incompletas. "Às vezes eles têm de sofrer, mas jamais conseguem fazer algo. A sociedade lhes é surda e implacável. Eles não sabem se adaptar às condições, nenhum chegou a chefe de seção. Outros se consolam tornando-se professores e trabalhando para a geração futura." A utilidade negativa que trazem é indubitável. Eles multiplicam o número de pessoas não aptas à atividade prática e, consequentemente, a própria atividade prática, ou melhor, as formas em que ela geralmente se expressa, é lenta e constantemente rebaixada na visão da sociedade.

"Parecia (depois da campanha da Criméia) que o rudinismo estava chegando ao fim, que depois da época de sonhos e aspirações estéreis chegava a época da ação efervescente e útil. No entanto, a miragem se desfez. Os Rúdin não se tornaram ativistas práticos, depois deles surgiu uma nova geração, que tratava seus predecessores com reprovação e zombaria. "De que se lamuriam, o que buscam, o que querem da vida? Decerto querem felicidade. Mas isso é pouco! É preciso lutar pela felicidade. Se têm forças, agarrem-na. Se não há forças: cale-se, pois mesmo sem os senhores já é nauseante". Uma energia soturna e concentrada se faz sentir nessa atitude animosa da 
jovem geração em relação aos seus preceptores. Em suas noções sobre o bem e o mal, essa geração convergia com as melhores pessoas da geração anterior, as simpatias e antipatias eram comuns; os desejos eram exatamente os mesmos, mas as pessoas do passado deliravam e se agitavam. As pessoas do presente não deliram, nada buscam, não se submetem a quaisquer acordos e não têm quaisquer esperanças. Elas são tão impotentes quanto Rúdin, mas tomaram consciência de sua impotência.

"'Não posso agir agora - pensa cada uma dessas pessoas novas -, não vou nem tentar, eu desprezo tudo que me cerca e não buscarei esconder meu desprezo. Tomarei parte na luta contra o mal quando me sentir forte.' Impossibilitadas de agir, essas pessoas começam a pensar e pesquisar... Superstições e autoridades quebram-se em mil pedaços e a visão de mundo é totalmente depurada de diversas noções ilusórias. A elas não importa se a sociedade segue seus passos; são cheias de si mesmas, de suas vidas interiores. Em uma palavra: os Petchórin possuem uma vontade sem conhecimento; os Rúdin possuem um conhecimento sem vontade; os Bazárov possuem tanto conhecimento quanto vontade. Pensamento e ação se fundem em um todo sólido."

Como veem, aqui há de tudo, se não houver erro, ${ }^{6}$ tanto a caracterização quanto a classificação: tudo conciso e claro, a soma foi feita, a conta foi entregue e, do ponto de vista a partir do qual o autor trata a questão, ela está absolutamente correta.

Mas não aceitamos essa conta e protestamos contra ela de nossas sepulturas prematuras e ainda não abertas. Não somos Carlos V e não queremos de modo algum ser enterrados como cavalos ruços. ${ }^{7}$

Como são estranhos os destinos dos pais e filhos! Que Turguêniev não criou Bazárov para passar a mão em sua cabeça, isso é claro; o que ele quis fazer em prol dos pais, isso também

6 Herzen parafraseia as palavras de Famússov na comédia de Griboiédov A desgraça de ter espírito, "Aqui há de tudo, menos mentira" (Ato 1, cena 4).

7 Carlos V, imperador do Sacro Império Romano-Germânico, que abdicou do trono em 1555 e partiu para um monastério. 
é claro. Mas no contato com pais tão deploráveis e insignificantes como Kirsánov, o robusto Bazárov arrastou Turguêniev, e este, em vez de açoitar o filho, vergastou os pais.

Disso decorreu que uma parte da jovem geração se reconheceu em Bazárov. Mas nós absolutamente não nos reconhecemos em Kirsánov, assim como não nos reconhecíamos nos Manílov ou nos Sobakiévitch, ${ }^{8}$ ainda que os Manílov e Sobakiévitch tivessem existido aos montes em nossa juventude e existam ainda hoje.

Nunca se sabe que rebanhos de abortos morais vivem numa mesma época nas diversas camadas da sociedade, em diferentes orientações; não há dúvidas de que eles representam mais ou menos um tipo comum, representam agora o aspecto mais agudo e característico de sua geração, o aspecto que melhor expressa sua intensidade. O Bazárov de Píssariev, num sentido unilateral, em certa medida é o tipo limítrofe daquilo que Turguêniev chamou de filhos, ao passo que os Kirsánov são os representantes mais apagados e vulgares dos pais.

Turguêniev foi mais artista em seu romance do que se pensa, e por isso se perdeu e, na minha opinião, fez muito bem: entrou em uma sala e foi parar em outra, ${ }^{9}$ que era ainda melhor.

Por que ele mandaria Bazárov para Londres? O miserável Píssemski não temia as despesas de viagem dos seus monstros perturbados. ${ }^{10}$ Nós, possivelmente, poderíamos provar para ele às margens do Tâmisa que talvez mesmo sem chegar a chefe de seçãoll seria possível oferecer tanto quanto qualquer chefe de departamento, que a sociedade nem sempre é surda e implacável quando o protesto desce o tom, que a ação

\footnotetext{
8 Ref. a personagens de Almas Mortas, de Nikolai Gógol. (N. das T.)

9 Citação de Griboiédov, A desgraça de ter espírito (Ato 1, cena 4).

10 No romance antinilista Mar agitado, publicado em 1863, Píssemski representa de maneira deformada a relação dos raznotchíntsy russos com a emigração londrina ao relatar a viagem para Londres de um dos heróis de seu romance. Sobre a referência a Herzen no romance de Píssemski cf. o artigo "Importação de imundícies de Londres" (vol. XVII desta edição). Sobre a relação entre Herzen e Píssemski cf. artigo de B. P. Kozmin "Píssemski e Herzen", Elos [Zvenia], vol. VIII, 1950, pp. 103-151.
}

11 Herzen parafraseia as palavras atribuídas ao herói Beltov de seu romance Quem é 0 culpado? (cf. vol. X desta edição, p. 319). 
às vezes é bem-sucedida, que os Rúdin e os Beltov às vezes possuem vontade e perseverança, e que ao verem a oportunidade de agir, pela qual ansiavam por seu pendor íntimo, eles largariam muitas coisas, fugiriam para o estrangeiro e organizariam, "sem delirar e se agitar", uma editora russa e toda a propaganda russa.

A influência da imprensa londrina de 1856 até o fim de 1863 é não apenas um fato prático, mas um fato histórico. É impossível apagá-lo, é preciso fazer as pazes com ele.

Em Londres, Bazárov veria que apenas de longe parece que estamos de mãos abanando, mas na realidade trabalhamos com elas. É possível que ele trocasse a fúria por clemência e deixasse de nos tratar com "reprovação e zombaria".

Confesso francamente que atirar pedras nos antecessores me é repugnante. Reitero o que disse:

Gostaria de salvar a jovem geração da ingratidão histórica e, quiçá, de um erro histórico. É chegada a hora de os pais de Saturno pararem de devorar os próprios filhos, mas também é hora de os filhos abandonarem o exemplo dos kamtchadals, ${ }^{12}$ que assassinam seus anciãos. ${ }^{13}$

Será que só a natureza tem o direito de ter suas fases e seus graus de desenvolvimento, seus desvios e afastamentos e até mesmo seus avortements ${ }^{14}$ analisados, examinados, ponderados sine ira et studio, ${ }^{15}$ mas quando se trata da história, em vez do método fisiológico recorre-se de imediato ao tribunal penal e à igreja? ${ }^{16}$

Os Onéguin e Petchórin passaram.

Os Rúdin e Beltov passam.

Os Bazárov passarão...

e muito em breve. São um tipo tenso, escolar, exaltado demais para conter-se por muito tempo.

12 Grupo étnico oriundo da península de Kamtchatka, no Extremo-Oriente russo (N. das T.). 13 Herzen cita o capítulo "I. I. Sazonov", escrito em 1863 e publicado inicialmente em Passado e pensamentos [Byloe i dumy], v. IV, Genebra, 1866, parte II, p. 338.

14 Em francês no original, "abortos". (N. das T.)

15 "Sem raiva e sem predileção" - citação dos Anais, de Tácito (cap. 1).

16 Em russo "blagotchiniia", plural de "blagotchiniie", reunião de paróquias de uma diocese na Igreja Ortodoxa Russa. (N. das T.) 
Um tipo apodrecido na flor da idade já implorava para substituí-lo, o tipo do estudante ortodoxo, do conservador e do patriota bolsista do Estado, ${ }^{17}$ no qual foi regurgitado tudo que havia de vil na Rússia Imperial, e o qual se confundiu, ele mesmo, após a serenata da Iverskaia e do louvor a Katkov. ${ }^{18}$

Passarão todos os tipos que surgiram; e todos, com a invencibilidade das forças outrora exaltadas que aprendemos a reconhecer no mundo físico, permanecerão e ascenderão, transformando-se no futuro movimento da Rússia e em sua futura estrutura.

E, portanto, não seria mais interessante, em vez de incitar Bazárov contra Rúdin, examinar em que consistem os fios condutores que os ligam e quais as causas de seu surgimento e suas transformações? Por que justamente essas formas de desenvolvimento foram apresentadas pela nossa vida, e por que elas assim passavam de uma a outra? Sua discrepância é evidente, mas de algum modo elas também já estavam próximas uma da outra.

Os tipos captam facilmente a distinção, aumentam seus ângulos e saliências para ganhar profundidade, contornam com tinta espessa os limites, rompem os laços. Perdem-se as modulações e a unidade fica ao longe, atrás da névoa, como um campo que reúne as bases da montanha, distantes umas das outras, com picos intensamente iluminados.

Além disso, nós colocamos nos ombros dos tipos mais do que eles conseguem suportar e lhes damos um significado na vida que eles não possuíam, ou possuíam de forma limitada. Tomar Oniéguin por um tipo positivo da vida intelectual dos anos 1820 é totalmente errado, ainda que ele represente um dos aspectos da vida de então.

\footnotetext{
17 Em russo, "kazionnokochtnyi", estudantes mantidos pelos fundos estatais.

18 No artigo ["Tudo e mais um pouco da nossa reação" ["Vsiakaia vsiatchina iz nachei reaktsii"], Herzen escreveu sobre a participação de um grupo de estudantes da Universidade de Moscou nos "louvores" na capela Nossa Senhora Iverskaia, de 7 a 10 de abril de 1866, pela recuperação de Aleksandr II do tiro disparado por D. V. Karakozov. À época dessas "celebrações populares", os estudantes aplaudiram de pé os editores do Notícias de Moscou [Moskovskie vedomosti], M. N. Katkov e P. M Leontiev.
} 
O tipo daquela época, um dos mais magníficos da história recente, é o dezembrista, não Oniéguin. A literatura russa não conseguiu abordá-lo por quarenta anos, mas ele não se tornou menor por isso.

Como é possível ter faltado à geração jovem a perspicácia, o tato e o coração para compreender toda a grandeza, toda a força daquela juventude brilhante, oriunda das fileiras militares, dos queridinhos da nobreza, da riqueza, aqueles que deixaram seus salões e montes de ouro para reivindicar direitos humanos, para protestar, para denunciar, denúncia em função da qual - e eles sabiam disso - esperavam-nos a corda do carrasco e os trabalhos forçados? Este é um triste enigma.

Não faz sentido irritar-se com o fato de essas pessoas surgirem na única classe na qual havia alguma instrução, diversão e opulência. Se esses "príncipes, boiardos, autoridades militares", ${ }^{19}$ esses secretários de Estado e coronéis não tivessem sido os primeiros a serem despertados pela fome moral, se eles tivessem esperado que sua fome física os acordasse, então não haveria nem os desvairados e inquietos Rúdin, tampouco os Bazárov adormecidos em sua "unidade de liberdade e conhecimento". E haveria algum médico de regimento que mataria os soldados de fome, roubando-lhes a ração e os medicamentos, e que venderia ao administrador de Kirsánov declarações de morte natural de camponeses açoitados; ou um burocrata-corrupto, sempre bêbado, que sugaria os tostões dos camponeses enquanto ajuda sua excelência, o governador Kirsánov, a vestir o capote e as botas? Além disso, não teria havido nenhum golpe fatal na servidão, nem tudo o que opera sob a pesada crosta do poder, minando o arminho imperial e o roupão acolchoado do proprietário de terras.

Felizmente, junto às pessoas cujas aventuras fidalgas se compunham de canil e criadagem, de violência e açoitamento doméstico, de servilismo em Petersburgo, encontravam-se aqueles cujas "aventuras" consistiam em arrancar a chibata de suas mãos e conquistar amplidão - não arrojo num campo afastado, mas amplidão para a mente e a vida humana. Se tal

19 Citação da tragédia "Dimitri Donskoi" de V. A. Ozerov (ato I, cena I). 
intento foi um assunto sério, uma paixão, eles o mostraram na forca, nos trabalhos forçados... eles o mostraram ao retornar da Sibéria trinta anos depois.

Se o tipo do dezembrista se refletiu em alguém na literatura - debilmente, mas com características afins -, foi em Tchátski. ${ }^{20}$

Em seu pensamento exacerbado e amargo, em sua indignação juvenil, ouve-se um impulso saudável pelo trabalho, ele sente o porquê de sua insatisfação, ele bate a cabeça na parede de pedra dos preconceitos sociais e tenta ver se são fortes as grades estatais. Tchátski foi direto ao caminho do trabalho forçado, e se sobreviveu ao 14 de dezembro, então provavelmente não se tornou nem terrivelmente nostálgico, nem orgulhosamente desdenhoso. Ele se atiraria depressa na indignação exagerada, como Tchaadáiev, tornar-se-ia um católico, odiador dos eslavos ou um eslavófilo, mas não abandonaria, em hipótese alguma, sua propaganda, como não a abandonava nem mesmo na sala de visitas de Famussov ${ }^{21}$ ou em seu salão, tampouco se acalmaria com o pensamento de que "sua hora não chegara". Ele tinha aquela persistência irrequieta que não consegue suportar a dissonância com o entorno e deve quebrá-la ou quebrar-se. Esta é a fermentação graças à qual a estagnação na história é impossível, pela qual é impossível o mofo em sua onda corrente, ainda que desacelerada.

Se Tchátski tivesse sobrevivido à primeira geração, que se seguiu à de 14 de dezembro, com medo e tremor, achatado pelo terror, aplainado, esmagado, teria, por meio dela, nos estendido suas mãos quentes. Conosco, Tchátski retornou ao seu solo. Estas rimes croisées $^{22}$ através das gerações não são raras, mesmo em zoologia. E estou totalmente convencido de que me entenderia bem com os filhos de Bazárov, e eles comigo - "sem amargura e zombaria". Tchátski não poderia ter vivido ociosamente, nem em rabugice caprichosa, tampouco em

20 Aleksandr Tchatski, protagonista da peça A desgraça de ter espírito, de A. Griboiédov. (N. das T.)

21 Pável Famussov, personagem de A desgraça de ter espírito. Ver nota 9. (N. das T.)

22 Em francês no original, "rimas cruzadas". (N. das T.) 
autodeificação arrogante; ele não era velho o suficiente para encontrar prazer na rabugice diária, nem era tão jovem para desfrutar da autossatisfação adolescente. Nesse caráter de fermento inquieto, de viva levedura, está toda a sua essência.

Entretanto, é justamente esse lado que desagrada a Bazárov e que o exacerba em seu estoicismo orgulhoso. "Fique quieto no seu canto se lhe falta a força para fazer algo, já está ruim sem suas lamúrias nauseabundas", diz ele, "Foi agredido, pois bem, fique aí agredido... O que é isso?! Por acaso não tem nada para comer? Por que chora? É tudo capricho de fidalgo" etc.

Píssariev deveria falar desse modo por Bazárov, seu papel assim o exigia.

É difícil não desempenhar um papel que está agradando. Tirem o uniforme de Bazárov, façam-no esquecer os jargões que emprega na fala, dê-lhe a liberdade de falar de forma simples, sem frases (ele que odeia frasismo!), falar uma palavra, deixe-o esquecer, por um minuto, seu punho de ferro, sua língua artificialmente seca, seu papel de instigador, e nós explicaremos todo o resto em uma hora.

"Em suas noções de bondade e maldade, a nova geração convergia com a anterior. Simpatias e antipatias eram comuns, ambas desejavam o mesmo... No fundo, elas reconhecem muito do que negam com as palavras", afirma Píssariev. Depois disso, é sensato concordar.

Mas até se despir dos paramentos, Bazárov exige que as pessoas sufocadas por tudo no mundo, ofendidas, martirizadas, privadas de sono e da capacidade de fazer algo na realidade, não falem sobre a dor. Isso resvala com força no araktcheievismo. $^{23}$

Com que fundamento, por exemplo, pode-se privar Liérmontov do direito à lamentação amarga e das críticas à sua geração, que fizeram tantos estremecer? Em que, de fato, teria sido melhor a prisão Nikoláievski se seus carcereiros fossem tão

23 Em russo, "araktcheievshchina", sistema de medidas e de reformas militares e policiais, comumente associado ao autoritarismo, que teve lugar no Império Russo no início do século XIX. O termo faz referência ao Conde A. Araktcheiev (1769-1834), oficial que iniciou as reformas. 
irritados, nervosos e impertinentes quanto Bazárov e reprimissem essas vozes?

- Para que elas servem? Qual a serventia?

- E por que a pedra faz barulho quando lhe batem com um martelo?

- Ele não consegue evitar.

- E por que esses senhores acham que as pessoas podem sofrer por gerações inteiras, em silêncio, sem queixas, indignações, imprecações, protestos? Se as queixas não são necessárias aos outros, elas o são para os próprios queixosos. A tristeza expressa alivia a dor. "Ihm gab ein Gott zu sagen, was er leidet", ${ }^{24}$ diz Goethe.

- O que temos a ver com isso?

- Os senhores, talvez, nada; outros talvez tenham; mas não se deve perder de vista que cada geração vive também para si. Do ponto de vista da história, é uma transição, mas em relação a si mesmo, isto não pode ser um objetivo, não se deve, resignado, aguentar sobre si as adversidades - sobretudo sem o consolo que possuía Israel à espera do Messias, e sem saber, de modo algum, que da semente dos Oniéguin e dos Rúdin nasceria Bazárov.

Em essência, nossos jovens se enfurecem com o fato de que em nossa geração se manifestava de uma forma diferente a nossa necessidade de atividade, o nosso protesto contra o que existia, e pelo fato de a motivação de um e de outro nem sempre, nem completamente, ter dependido da fome e do frio.

Não foi essa paixão pela uniformidade, vindo desse mesmo espírito irritadiço, que transformou, entre nós, a forma essencialmente burocrática e as evoluções militares em floreios de marcha militar? A partir desse aspecto do caráter russo, desenvolveu-se o araktcheievismo civil e militar. Qualquer manifestação pessoal ou individual, qualquer retirada, era considerada uma transgressão e suscitava perseguições e incessantes críticas imotivadas. Bazárov não deixa ninguém em

24 Citação imprecisa da peça de Goethe Torquato Tasso (ato V, cena 5): "E quando um homem em seu tormento emudece,/ Dá-me um Deus para dizer o quanto padeço". (N. da T.) 
paz, provoca todos com desprezo. Cada palavra sua é uma reprimenda do superior ao inferior. Isso não tem futuro.

"Se o bazarovismo é uma doença, ele é o mal do nosso tempo e precisamos padecer dele", diz Píssariev.

Bem, é o bastante. Tal doença enfrenta-se só até o fim do curso universitário; como a dentição, ela não atingiu a maioridade.

O pior serviço que Turguêniev prestou a Bazárov foi, por não saber o que fazer com ele, condená-lo ao tifo. Trata-se da ultima ratio, ${ }^{25}$ contra a qual ninguém pode resistir. Se Bazárov tivesse sobrevivido ao tifo, é provável que ele, pelo menos, evoluísse do bazarovismo para a ciência, que ele amava e estimava, para a fisiologia, cujas técnicas não variam para uma rã ou uma pessoa, para a embriologia ou para a história.

"Bazárov arrancou de sua cabeça todos os tipos de preconceito, mas continuou sendo uma pessoa extremamente ignorante. Ele ouviu algo sobre poesia, sobre arte, não se deu ao trabalho de pensar e pronunciou precipitadamente um veredito sobre um objeto que lhe era desconhecido. Em geral, essa arrogância nos é peculiar, ela possui vantagens, como a audácia intelectual, no entanto, algumas vezes leva a erros grosseiros."

A ciência poderia salvar Bazárov, ele pararia de menosprezar as pessoas com um desdém profundo e indissimulado. A ciência nos ensina a humildade mais do que o evangelho. Ela não pode olhar nada com arrogância, ela não sabe o que é a arrogância, nada despreza, nunca mente para fazer tipo e nada esconde por coquetismo. Ela se detém ante os fatos como um pesquisador, às vezes como um médico, mas nunca como algoz, muito menos com hostilidade e ironia.

A ciência - eu não sou obrigado esconder algumas palavras no silêncio da alma -, a ciência é amor, como disse Spinoza sobre o pensamento e o entendimento.

25 Do latim, "argumento decisivo". 


\section{Segunda carta}

O passado deixa uma pegada na história, por meio da qual a ciência, cedo ou tarde, restaura o que passou em suas características fundamentais. Perde-se a iluminação acidental, de um certo ângulo sob o qual ele aconteceu. Apoteose e calúnia, vício e inveja - tudo desaparece e é soprado para longe. A pegada leve, coberta de areia, some; o pé tendo força e perseverança imprime-se numa pedra e ressuscitará pelas mãos de um trabalhador honesto.

Laços, graus de parentesco, os que deixam a herança e os que a herdam, bem como os seus direitos recíprocos: tudo se revelará pela heráldica da ciência.

Sem antepassados, nascerão somente deusas, como Vênus da espuma do mar. Minerva, mais inteligente que ela, nasceu da cabeça de Júpiter.

Os dezembristas são nossos grandes pais e os Bazárov são nossos filhos pródigos.

Dos dezembristas herdamos o senso aguçado de dignidade humana, o anseio por independência, o ódio à escravidão, 0 respeito ao Ocidente e à revolução, a fé na possibilidade de uma reviravolta na Rússia, um desejo apaixonado de juntar-se a ele, a juventude e a integridade das forças.

Tudo isso foi retrabalhado, tornou-se outra coisa, mas as bases mantiveram-se intactas.

E o que a nossa geração legou à nova?

O niilismo.

Relembremos um pouco como isso se deu.

Por volta dos anos quarenta, sob válvulas pressionadas com intensidade, a vida começou a surgir com mais força. Em toda a Rússia chegou uma mudança sutil, o tipo de mudança por meio da qual um médico percebe antes de relatar que há uma melhora no quadro da doença, como se forças muito fracas fossem reavivadas - um tom diferente. Em algum lugar lá dentro, em um mundo moral microscópico, um ar diferente 
soprou, mais irritadiço, mas também mais saudável. Por fora, tudo estava morto sob o gelo de Nicolau, ${ }^{26}$ mas algo despertou na consciência, no entendimento - certa sensação de inabilidade, de desprazer. O horror diminuiu, as pessoas se cansaram no crepúsculo do reino das trevas.

Eu vi essa mudança com meus próprios olhos ao chegar do exílio inicialmente em Moscou e depois em Petersburgo. Mas eu via isso nos círculos dos literatos e dos cientistas. Outra pessoa, cuja antipatia báltica pelo movimento russo coloca a suspeita acima da predileção, há não muito tempo confessou ter ficado perplexo com o afrouxamento da disciplina depois de retornar, nos anos 1840, à aristocracia militar de São Petersburgo, após vários anos ausente. Os ajudantes de campo e os coronéis da guarda, queixavam-se, criticavam as medidas do governo, estavam insatisfeitos com o próprio Nicolau. Ele ficou a tal ponto aturdido, amargurado, assustado com o futuro da autocracia, que na confusão de seu espírito, durante um jantar na casa do ajudante de campo B., quase como se estivesse na presença do próprio Dubelt, sentiu como se entre 0 queijo e a pera tivesse nascido o niilismo. ${ }^{27}$

Ele não reconheceu o recém-nascido, mas estava lá. A máquina aparafusada por Nicolau estava cedendo, ele soltou o parafuso e todos perceberam, alguns falavam, outros, proibidos de falar, calavam, mas tanto uns como outros entenderam que, em essência, tudo ia mal, tudo estava pesado para todos e ninguém podia tirar proveito desse peso.

Aos negócios veio se misturar o riso, um péssimo camarada em qualquer religião, e a autocracia é uma religião. A torpeza e a negligência da baixa administração foram tamanhas que o governo a abandonou à zombaria. Nicolau Pávlovitch, que morreu de rir em seu camarote com Skvoznik-Dmukhanovski

26 Ref. ao tsar Nicolau I (1796-1855), cujo reinado caracterizou-se pelo conservadorismo e 0 alto grau de repressão. ( $\mathrm{N}$ das T.)

27 Herzen refere-se ao barão F. I. Fiks (Chedo-Ferroti), que em seu livro de ensaios Études sur l'avenir de la Russe. Nihilisme en Russie, contou que ao voltar a São Petersburgo depois de nove anos de ausência, esteve "em um jantar com o senhor B.", onde doze pessoas da alta sociedade - "príncipe K., conde T., conde S., senador J., general D. 'Dubbelt"' e outros -, reunidos à mesa, criticaram as medidas do governo em relação à disciplina e às finanças. 
e Derjimorda, ${ }^{28}$ ajudou na propaganda, sem supor que o riso, depois da aprovação de Vossa Alteza, subiu com rapidez na tabela de patentes.

Aplicar à época as rubricas de Píssarev é difícil. Na vida, tudo consiste em transbordamentos, oscilações, intersecções, arrebatamento e interceptação, e não em pedaços quebrados.

Onde acabam as pessoas sem conhecimento mas com vontade e começam as pessoas com conhecimento e sem vontade?

A natureza escapa resoluta da fila do pelotão, e até mesmo da fila etária. Liérmontov foi camarada de Bielínski por anos, frequentou a universidade com ele, mas morreu na irremediável desesperança, seguindo o caminho de Petchórin, contra o qual, tanto nós como os eslavófilos nos rebelamos.

A propósito dos eslavófilos: onde enfiar Khomiakov e seus "irmãozinhos"? O que eles possuíam: vontade sem conhecimento ou conhecimento sem vontade? E eles assumiram um lugar nada insignificante no novo desenvolvimento da Rússia, eles imprimiram o próprio pensamento na corrente contemporânea.

Ou ainda: em que frente de recrutamento e em que medida colocamos Gógol? Conhecimento ele não tinha; se tinha vontade, não sei e duvido; mas gênio ele foi, e sua influência foi colossal.

Pois bem, deixemos de lado o lapides crescunt, planta crescunt et vivunt de Píssariev e sigamos adiante. ${ }^{29}$

Não havia sociedades secretas, mas o acordo secreto dos entendidos era grande. Os círculos, formados por pessoas que vivenciaram em maior ou menor intensidade o peso da pata de urso do governo, acompanharam de perto a sua composição. Qualquer outra ação, exceto a palavra, e ainda assim disfarçada, era impossível. No entanto, a palavra ganhou força, não apenas a impressa, porém mais ainda a palavra viva, menos perceptível para a polícia.

28 Personagens de 0 inspetor geral, comédia de Nikolai Gógol que satiriza a burocracia e a corrupção no Império Russo. Herzen faz referência à noite de estreia da comédia, em que, segundo vários relatos, o tsar Nicolau I esteve presente e riu muito. (N. da T.)

29 Do latim, "as pedras crescem, as plantas crescem e vivem". (N. da T.) 
Duas baterias avançaram rapidamente. A literatura em periódicos torna-se propaganda; na sua liderança, no auge de suas forças da juventude, está Bielínski. Os departamentos das universidades estão se convertendo em altar, as aulas, em sermões de humanização; a personalidade de [Timofiêi] Granóvski, cercada de jovens professores associados, se sobressai mais e mais.

De repente, outra explosão de riso. Um riso estranho, um riso terrível, um riso convulsivo, no qual havia vergonha e remorso, e talvez não fosse do riso às lágrimas, mas das lágrimas ao riso. O mundo absurdo, monstruoso e estreito de Almas mortas não aguentou, até o burro se afastou. E o sermão era mais forte ... sempre o mesmo sermão - o riso e o choro, o livro e o discurso, Hegel $^{30} \mathrm{e}$ a história: tudo chamava as pessoas à consciência de sua posição, ao horror diante da servidão e de sua própria falta de direitos, tudo apontava para ciência e educação, para purificação do pensamento de toda a tralha convencional, para a liberdade da consciência e da razão.

Os primeiros lampejos do niilismo pertencem a esse tempo; lampejos da mais perfeita liberdade em relação a todas as ideias prontas, a todas as obstruções e todos os amontoados herdados que impedem a mente ocidental de seguir em frente com seu núcleo histórico em pé...

O trabalho silencioso dos anos quarenta foi interrompido abruptamente. Os tempos mais sombrios e difíceis do início do reinado de Nicolau vieram depois da Revolução de fevereiro. Bielínski morreu antes do início da repressão. Granóvski o invejou e se esforçou para deixar sua pátria. ${ }^{31}$

30 A dialética de Hegel é um terrível aríete; apesar de sua duplicidade e da insígnia prussiano-protestante, ela fez evaporar tudo o que existia e dissolveu tudo o que atrapalhava a razão. Além disso, era a época de Feuerbach, der kritischen Kritik... (N. do A.)

31 Herzen refere-se à carta de T. N. Granóvski de junho de 1849, que diz "Bem-aventurado Bielínski, que morreu a tempo", publicada em PZ, 1859, v. 5, p. 216 (ver Elos, v. VI, 1936, p. 361). Há evidências diretas das intenções de Granóvski de "deixar a pátria" na correspondência não publicada entre Herzen e A. Kolatchek (guardada na República Democrática Alemã, onde foi preparada e publicada por G. Ziegengeist). As cartas de Granóvski a Herzen entre 1849 e 1855 mencionavam algumas vezes a possível viagem de Granóvski ao exterior (ver $L N$, vol. 62, pp. 98, 100, 104). 
Uma noite escura de sete anos caiu sobre a Rússia, e foi nela que se formou, se desenvolveu e se fortaleceu na mente russa aquele pensamento, aquela forma de pensar chamada niilismo.

O niilismo (repito o que disse recentemente em $O$ sino) ${ }^{32}$ é a lógica sem restrição, ${ }^{33}$ é a ciência sem dogmas, é a obediência incondicional à experiência e a aceitação resignada de todas as consequências, quaisquer que sejam, desde que decorram da observação e sejam exigidas pela razão. 0 niilismo não converte algo em nada, mas revela que o nada tomado por algo é uma ilusão de ótica, e que toda verdade, ainda que contradiga as ideias fantasiosas, é mais saudável do que elas e, em todo caso, obrigatória.

Seja esse nome adequado ou não, tanto faz. Acostumaram-se com ele, foi aceito por amigos e inimigos, tornou-se um sinal policial, virou denúncia e insulto para uns, elogio para outros. É claro que se por niilismo queremos dizer criação inversa, isto é, a transformação de fatos e pensamentos em nada, em ceticismo estéril, em arrogantes "braços cruzados", em desespero que leva à inação, então cada vez menos os niilistas verdadeiros se encaixam nesta definição e um dos maiores niilistas será Ivan Turguêniev, que lhes atirou a primeira pedra, e, talvez, seu filósofo favorito, Schopenhauer.

Quando Bielínski, depois de ouvir longamente as explicações de um de seus amigos de que o espírito vem à autoconsciência na pessoa, respondeu indignado: "Então eu não percebo as coisas para mim, mas para o espírito... Por que eu devo ser seu tolo? Melhor parar de pensar, de que me importa sua consciência?...", ele foi um niilista.

Quando Bakunin acusou os professores de Berlim de temerem a negação e os revolucionários parisienses de 1848 de conservadorismo, ${ }^{34}$ ele foi totalmente niilista. Em geral, toda

32 Herzen expôs suas reflexões sobre a essência do nilismo russo no artigo "A ordem triunfa!", publicado entre janeiro e fevereiro de 1867 em 0 sino [Kólokol] de , 230, 231-32 e 233-34 de 1 de dezembro de 1866. (N. da T.)

33 Sem fronteiras, do latim strictura. (N. da T.)

34 Em seu Passado e pensamentos, Herzen diz que nos primeiros dias após a Revolução 
essa vigilância e recusa ciumenta não levam a lugar algum, exceto ao antagonismo violento.

Quando os membros do círculo de Petrachévski foram condenados aos trabalhos forçados porque "queriam subverter todas as leis divinas e humanas e destruir os fundamentos da sociedade", como se lê na sentença, roubando expressões da nota inquisitorial de Liprandi, ${ }^{35}$ eles foram niilistas.

Desde então, o niilismo se expandiu, tomou consciência de si mesmo com mais clareza, tornou-se em parte uma doutrina, tomou para si muito da ciência e convocou figuras de enorme força e talentos... tudo isso é inegável.

Mas ele não introduziu novos preceitos e princípios.

Ou onde estariam eles?

Sobre isso, espero uma resposta sua, ou talvez de outra pessoa, e só depois continuarei.

\section{Comentário}

$\mathrm{O}$ artigo foi pensado por Herzen ainda em janeiro de 1868 . Em 8 de janeiro de 1868, Herzen escreveu para Ogarióv a respeito da leitura das Obras de D. I. Píssariev, publicada em Petersburgo entre 1866 e 1869 (o artigo "Bazárov", de 1862, foi incluído no primeiro tomo, que saiu em 1866): "Pagaria bem se pudesse passar os olhos no livro que me traz uma satisfação tão inquietante, as Obras de Píssariev [...], ele me fez olhar de outra forma para o romance de Turguén[iev] e para Bazárov. É possível que eu escreva algo sobre ele". A primeira versão do artigo, que não chegou até nós, provavelmente foi escrita e enviada pouco depois para Ogarióv. Em 18 de fevereiro, Herzen escreveu-lhe: "Espero resposta sobre "Bazárov". O artigo

de fevereiro de 1848 Bakunin pregou por dias a "revolução en permanence, guerra até que 0 último inimigo fosse derrotado", o que causou insatisfação nos círculos de revolucionários parisienses, os quais consideraram necessário removê-lo de Paris em maio do mesmo ano.

35 Ivan Liprandi foi o oficial do Ministério do Interior responsável pela Comissão de Inquérito do caso Petrachévski, no qual vários membros da intelectualidade foram presos e enviados aos trabalhos forçados, entre eles Fiódor Dostoiévski. (N. da T.) 
de Herzen despertou uma reação negativa de Ogarióv. No que parece claramente ser uma resposta ao conselho dado por este em carta que nos é desconhecida, isto é, interromper o trabalho no artigo, Herzen escreveu-lhe em 27 de abril: "Não posso largar 'Bazárov'. Estou refazendo-o em cartas e deixarei numa pasta por um ano. Retirei dele a aspérité [aspereza], e posso jurar que não é apenas um artigo verdadeiro, mas útil". Em carta sem data, provavelmente de maio de 1868, Herzen escreveu: "Sou como Stratford: je me laisse exécuter en gentleman [permito ser executado como um gentleman] e entrego Bazárov para a câmara de armas de ferro até outro tempo. É possível que você esteja certo, mas eu sacrifico o errado [...] Cedo ou tarde, colocarei neles o chapéu de tolo, mas a edição de 1869 de Estrela Polar [Poliarnáia Zvezdá] não será o palco de execução deles. Esperei a resposta deles, e então lançaria meus batalhões".

Em 1869, tendo mudado sua intenção inicial de não publicar o artigo em Estrela Polar, Herzen logo passou a retrabalhá-lo. Possivelmente o estímulo para isso foi o seguinte fato: na gráfica de Elpidin, em Genebra, foi impresso o primeiro tomo da Obra reunida de N. G. Tchernichévski, em cujo prefácio anônimo dizia-se que "as pessoas dos anos 1840", antes de tudo, temiam "ser privadas de alguma forma da tranquilidade e do conforto alcançados", mas, ainda assim, desejavam "parecer ativistas que não perderam o ânimo e que, como antes, odiavam o jugo selvagem". Em 15 de maio de 1868, Herzen escreveu a Ogarióv a esse respeito: "Nikoladze, no prefácio a Tchernichévski, ofendeu-nos com aquele mesmo ponto de vista de Píssariev e Bazárov". Depois disso, Herzen possivelmente voltou ao seu artigo sobre Bazárov, dando-lhe a forma de cartas a Ogarióv. Já na primeira quinzena de junho de 1868, estava terminada a primeira carta. Em 16 de junho, escreveu a Ogarióv: "Envio-lhe a primeira parte de 'Bazárov', trabalhei nela e esqueci de entregar. Tente ler com sangue frio e repasse a Tcherniétski ou dê imprimatur [autorização para imprimir]. Em 20 de junho, ele escreveu a Ogarióv: "Não insistirei novamente em 'Bazárov', a segunda carta está pronta, eu a enviarei nos próximos dias". Herzen enviou a segunda carta a Ogarióv 
em lo de julho, dando-lhe o direito de "excluir tudo aquilo que achar necessário". Não se exclui a possibilidade de que, na primeira carta, Ogarióv tenha feito algumas correções. Quanto à segunda carta, ele informou a Herzen em 5 de julho que "nessa seção de 'Bazárov' [...] não encontrei nada a ser corrigido, exceto ninharias gramaticais, e não muitas".

A edição de 1869 de Estrela Polar veio à luz em novembro de 1868.

$\mathrm{O}$ anúncio sobre as vendas de Estrela Polar foi publicado em O sino [KólokoI], n. 14-15, no lo de dezembro de 1868.

No artigo "Outra vez Bazárov", Herzen sublinha seu interesse não pela conceito turguenieviano de Bazárov: trata-se fundamentalmente do bazarovismo como "ideal do senhor Píssariev", um ideal que "foi defendido pela geração jovem antes do Bazárov de Turguêniev e depois dele".

Em suas manifestações anteriores sobre o herói de Turguêniev, Herzen, ao avaliar a força necessária e o significado da imagem de Bazárov como um todo, observou que o ceticismo universal, a "negação total" niilista, o apego ao materialismo vulgar e, por outro lado, a rispidez e a autoconfiança, estão longes de ser traços típicos de figuras como Bazárov.

Herzen escreveu para Turguêniev em 21 de abril de 1862: "Parece-me que você [...] se deteve na exterioridade insolente, quebrada, biliar, na virada plebeia/pequeno-burguesa e, ao tomar isso como ofensa, seguiu adiante. Mas onde está a explicação de como sua jovem alma se fez insensível por fora, canhestra, irritadiça [...]. O que fez retroceder toda a ternura, o caráter expansivo? Não foi o livro de Büchner? Em geral, parece-me que você está sendo injusto para com uma visão séria, realista e experiente que pode se confundir com certo materialismo grosseiro, vanglorioso, só que isso não é culpa do materialismo, mas dos Neuvajai-Koryto que o compreendem bestialmente".

No artigo "Uma nova fase na literatura russa", Herzen escreveu em relação à imagem de Bazárov: "Falar sobre o niilismo dos jovens ardorosos e leais, que apenas se fazem de céticos desesperados, é um erro grosseiro". 
No artigo "Bazárov", Píssariev, ao contrário, reconheceu esses traços contestados por Herzen como característicos do herói de Pais e filhos, e em alguma medida até os levantou como um escudo, como sendo supostamente propriedades inalienáveis dos revolucionários dos anos 1860.

Contudo, o alvo da crítica de Herzen no artigo aqui comentado é não apenas e não tanto o fato de que "o Bazárov de Píssariev, num sentido unilateral, em certa medida é o tipo limite daquilo que Turguêniev chamou de filhos", mas as representações vivas e concretas da geração dos "filhos", alguns dos quais eram ativistas da "jovem emigração" suiça.

Em 1868, depois da publicação da brochura de A. A. Serno-Solovievitch "Nosso caso doméstico", a relação entre Herzen e uma série de representantes da emigração russa na Suíça agravou-se fortemente. $O$ motivo do embate eram divergências sobre algumas questões atuais da organização (a conversão d'O Sino em um órgão geral da emigração, o uso de fundos especiais que estavam à disposição de Herzen e Ogarióv etc). Mas o principal eram a mútua incompreensão e irritação ligada a aspectos de ordem mais geral: o pertencimento a diferentes gerações revolucionárias, a subestimação por parte da "jovem emigração" dos serviços prestados por Herzen pelo movimento de liberação russo, a inclinação de certos membros da "juventude" revolucionária a exagerar o significado de certos equívocos e fracassos de Herzen. Para um correto entendimento das divergências entre Herzen e a "jovem emigração" é preciso levar em conta as condições extremamente anormais existentes à época na Suíça para muitos jovens emigrantes devido à falta de ação revolucionária prática, ao prolongado afastamento da pátria, à falta de coesão ideológica, à insegurança material etc.

Tudo o que foi dito explica a estranheza e o caráter contraditório das reações de Herzen sobre a nova geração de revolucionários russos. No capítulo "Jovem emigração" de Passado e pensamentos (parte sete), Herzen fala da "jovem emigração" como "jovens navegantes da tormenta futura", mas a acusa ao mesmo tempo de vaidade exacerbada, rispidez desmedida, es- 
treiteza etc., denominando os seus representantes mais "ferozes" de "Os Sobakiévitch e os Nozdrióv do niilismo".

A respeito da interrupção da publicação d'O Sino, Herzen escreveu a Ogarióv em dezembro de 1868: "Existe uma juventude tão profunda e irrevogavelmente devotada ao socialismo, tão atravessada por uma lógica destemida, tão fortalecida pelo realismo científico e pela recusa em todos os campos do fetichismo clerical e governamental, que podemos não ter medo: a ideia não morrerá".

Ao mesmo tempo, justamente contra certos representantes da juventude revolucionária, contra a "jovem emigração" suíça, são endereçados seus comentários mais ásperos no artigo aqui comentado. Na interpretação de Píssariev do personagem de Turguêniev, tomaram um espaço desproporcional os traços que foram reconhecidos por Herzen em carta a Turguêniev de 21 de abril de 1862, não característicos dos revolucionários dos anos 1860 ("materialismo grosseiro, vanglorioso", "insolência", "canhestra" etc.). Agora, Herzen os emprega com o objetivo de polemizar com a "jovem emigração". O Bazárov de Píssariev, segundo a pena de Herzen, torna-se como que a personificação de tudo aquilo que ele condena em representantes como A. A. Serno-Solovievitch, N. A. Vorms, N. Ia. Nikoladze, M. K. Elpidin etc.

Em carta a Ogarióv datada por volta de maio de 1868, Herzen escreve sobre o Bazárov de Píssariev: "Seu tipo de Bazárov é precisamente o verdadeiro [...]. Sim, é o ideal de todo radical do niilismo [...]. Eu os detesto e gostaria de ridicularizá-los. Mas o que me incomoda é a ingratidão deles em relação a todos que vieram antes, inclusive a nós; esse sentimento é verdadeiro e não há nada de que se envergonhar. Aquele que se superestima é ridículo, aquele que não se valoriza, por sua vez, é deplorável".

Em 24 de abril de 1868, Herzen, ao informar Ogarióv sobre o recebimento de uma carta de N. A. Vorms, anuncia: "Acredite, enquanto eu não me lançar sobre o focinho desses senhores de uma vez chamando-os de Bazárov ou de alguma outra coisa, eles não me deixarão em paz". Em seguida, em carta de 29 
de abril de 1868, "Turg[uêniev] estava apenas brincando com eles. Eles devem ser pendurados no pilar da vergonha". Em carta a Ogarióv de 2 de maio de 1868, Herzen observa: "Aqui um dos jovens, um Bazárov, agrediu a própria mãe com um martelo; o Bazárov de Turguêniev é um deus perto desses porcos". "Quanto a Bazár[ov], esqueça-se de Turguêniev, dispense nossos populares [...] Bazárov é moralmente superior ao bazaróides subsequentes." (Carta a Ogarióv de 7 de maio de 1868.)

Em relação ao que foi dito, adquirem significado especial as ênfases dadas por Herzen ao citar o artigo de Píssariev. Em uma série de ocasiões, Herzen recorre aos itálicos para ressaltar os traços que lhe pareciam mais antipáticos no bazarovismo. Assim, por exemplo, são destacados o "caráter imotivado" e a "falta de objetivo" da rispidez de Bazárov, ele pode ser satisfeito apenas por "toda a eternidade de uma atividade em constante expansão e de uma satisfação em constante crescimento", são destacadas a hostilidade "com reprovação e zombaria", a relação dos Bazárov com seus antecessores, o desprezo deles a tudo o que os circunda etc.

Na disputa que Herzen trava em seu artigo com os "Bazárov" que lhe são contemporâneos, tem importância central a questão da contribuição de diferentes gerações de revolucionários russos à luta contra o tsarismo. Em um grau incomparavelmente maior do que os representantes da "jovem emigração", Herzen era caracterizado por uma compreensão da continuidade histórica da luta revolucionária. Por isso é compreensível o páthos com que ele fala da luta dos dezembristas contra a autocracia. Igualmente compreensível é o protesto duro de Herzen contra a desvalorização de Píssariev à "geração dos Beltov e Rúdin", a geração dos "pais" revolucionários, à qual pertence o próprio Herzen. Ao declarar que os "Rúdin e Beltov às vezes possuem vontade", ao indicar a "influência da imprensa londrina de 1856 até o final de 1863", Herzen inequivocamente faz oposição às tentativas de tais representantes da geração dos "filhos", como A. A. Serpo-Solovievitch, de contestar e rebaixar o papel dos criadores d'O Sino no movimento revolucionário russo. 
O "niilismo" de Bazárov, entendido como "materialismo grosseiro, vanglorioso", como menosprezo pela moral inabalável e pelos valores estéticos, não poderia ter agradado a Herzen. Em carta de 8 de janeiro de 1868 a Ogarióv, Herzen declarou sobre Píssariev: "Que lástima que só conheci esse macabeu do niilismo petersburguês tão tarde. Eis sua autoconsciência, sua autojustificação, feita não por um tolo, não por um vigarista, mas por um sujeito inteligente [...]. Ódio infinito por Púchkin, generosidade condescendente por Bielínski, e por nós uma atitude como se fossemos velhinhos irrequietos amalucados".

No artigo aqui comentado, contudo, essa compreensão da palavra "niilismo" é contraposta a outra, levantada por Herzen como escudo ("a mais perfeita liberdade em relação a todos os conceitos prontos, a todas as obstruções e todos os amontoados herdados"). Tal tratamento positivo do termo "niilismo" pode ser encontrado em Herzen também no artigo "Prevalece a ordem!" e na carta a Bakunin de 30 de maio de 1867, na qual afirma acerca da brochura de A. Serno-Solovievitch, "Nosso caso doméstico": "Isso não é niilismo, o niilismo é um fenômeno grandioso no desenvolvimento russo". Na mesma carta de 8 de janeiro de 1868 a Ogarióv, na qual Herzen se detém tão detalhadamente no artigo "Outra vez Bazárov", ele aponta de forma significativa: "Eu distingui o bazarovismo e o niilismo de propósito".

Apesar da dura polêmica com a "jovem emigração", também entre 1868 e 1869 Herzen manteve relações de trabalho com alguns de seus representantes. A divergência capital em relação à visão de Píssariev enquanto autor do artigo "Bazárov" não impediu Herzen de, ainda em 1868, honrar com um afetuoso obituário a memória do crítico democrático revolucionário morto prematuramente.

Recebido em: 11/02/2021

Aceito em: 11/03/2021

Publicado em abril de 2021 